\title{
Student Perceived Value of Intensive Experiential Learning
}

\author{
Don R. May, Ph.D., P.E. \\ Department of Physics and Engineering \\ Fort Lewis College \\ Durango, CO 81301 \\ May_d@fortlewis.edu
}

\begin{abstract}
Experiential learning has become a common part of many engineering students undergraduate experience and is frequently accomplished using the service learning model. Intensive service learning for engineers is typically characterized by the type of "high risk" projects associated with developing world, humanitarian based service programs. In this research an expectancy-value theory model is used to evaluate student perceived value of service learning experiences. The model is applied to a case study where both engineering and non-engineering student participated in more than 25 projects over a 12 year period. Seventy-six percent of the respondents indicated that they most highly valued either the importance of the humanitarian mission or the impact of the experience on their perspective on life. Cost (monetary, time and effort) was ranked the least important factor. In all eight categories students rated the value (quality) of the experience higher than their expectation. Evidence suggests that, for engineering students, the value of the experience relative to their career should receive more emphasis and that professional role confidence may be an issue for female students. The results aid in assessing program efficacy and identifying areas where improvements can be achieved.
\end{abstract}

Index Terms - expectancy value theory, experiential learning, humanitarian engineering, student perceived value, service learning

\section{BACKGROUND}

\section{Motivation}

John Dewey, American philosopher and the presumptive father of progressive education, proposed a theory of experience which maintains that present experiences are uniquely tied to past experiences and the present situation ${ }^{1}$. He advocated that students should be actively involved in the learning process. Dewey, even in the early $20^{\text {th }}$ century, was a singular voice for educational reform and set the stage for the modern renaissance in experiential learning.

Experiential learning is an umbrella that encompasses many activities including internships, undergraduate research, community based research, study abroad, service learning, field work and others. It has become a common part of many engineering student's academic landscape. In some cases, such as internships, experiential learning is often embedded in the curriculum. However, many other opportunities exist that are co-curricular, for instance undergraduate research and elective service learning. Several factors motivate institutions to support experiential learning. These include the potential for a high impact on student development, improvement in student persistence to graduation, the recruiting effect and the positive impact on the receiving partners. While the potential payoff is significant, the cost in time, money and even 
non-tangible considerations such as risk liability are not insignificant. Confirming the worth of these investments is prudent. Objective evidence can be used to not only justify further investment but more importantly, improve the efficacy of programs.

What is the value of an experiential learning program? A part of the answer to this question is dependent on the perceived worth that students place on their experience. This paper describes a model that quantifies student perception of value for experiential learning activities.

\section{Intensive Service Learning}

Service learning (SL) is a form of experiential education that incorporates meaningful instruction and reflection with a service experience that benefits a community. The concepts of civic responsibility, altruism, strengthening communities and working for the common good are some of the fundamental principles. Sigmon ${ }^{2}$ suggested that SL only occurs when both the "provider" and the "recipient" gain from the experience. When a SL project is successfully executed, the community gains a valued outcome and students gain both educational and personal development value that cannot be found in the classroom.

Commonly, SL is associated with a specific college course and ties the course content to the service experience. This approach is student focused. However, a wider definition of service learning would include programs where the dominant focus is not placed on the student but on the receiving community. By doing this, the student inherently perceives that the world does not revolve around their needs but that the needs of the community are paramount. As a consequence, the student takes on the genuine role of "servant" (in the context of service provider) which, in effect, places higher value on their contribution. In concept, this realization heightens the student's sense of worth and increases the value of the experience.

$\mathrm{Kuh}^{3}$, in his seminal work on high impact educational practices, identifies 10 activities that can significantly influence a college student's success. He bases his findings on data from the National Study of Student Engagement ${ }^{4}$. Service learning and several activities that encompass the notions of collaboration, cultural exposure and research are among his all-star list of practices. Kuh pinpoints five factors that distinguished these. "First, these practices typically demand that students devote considerable time and effort to purposeful tasks. Second, the nature of these high-impact activities puts students in circumstances that essentially demand they interact with faculty and peers about substantive matters." Experiencing diversity, getting feedback on performance and applying what they learn in the classroom to real-world problems rounds out the list of factors. Kuh maintains that, when embedded in the undergraduate education, these practices offer the possibility of a life changing experience which understandably promotes student success. Roberts ${ }^{5}$ builds on Kuh's argument for experiential learning. He shares that in his many discussions with students, when asked, "where they think their deepest learning has taken place, they will sometimes point to one or two courses that had meaningful impact for them. But they almost always point enthusiastically to the co-curricular experiences in which they invested time and energy." Roberts concludes that despite all the evidence supporting the high value of experiential learning, it still remains on the margins in higher education.

Intensive service learning (ISL) is distinguished by being associated with service projects that inherently include very demanding yet realistic constraints and expectations. These are "high stakes" projects where the focus is placed on the receiving partner. The uncontrived nature of 
ISL projects intrinsically skews them towards failure, while at the same time offers the promise of greater benefit for the community and a higher impact on the student.

Over the past decade and a half, engineering education has spawned a host of ISL programs. Engineers Without Borders has been at the forefront of this movement but other similar, albeit much smaller, organizations have been developed at many schools including Clemson Engineers for Developing Countries, Engineering Students Without Borders at the University of Virginia, Engineers With a Mission at Baylor University, Engineers for a Sustainable World at Stanford and The Village Aid Project at Fort Lewis College.

These programs all share some basic characteristics. They offer students a chance to work, as volunteers, on projects in communities in the developing world. The projects are usually infrastructure related and address the basic needs of an underdeveloped population. Because of this, the consequences are not trivial. Success means improved quality of life for a village and failure means continued hardship and loss of confidence. Students perform genuine engineering design and complete real construction projects that are usually tightly constrained by limited resources. These are the type of "high stakes" factors that typify ISL projects.

\section{METHODS}

\section{Expectancy-Value Theory}

A great deal of work has been done on assessing the effectiveness of traditional SL projects that range from self-assessment ${ }^{6}$ to community partner assessments ${ }^{7}$ and overviews of assessment tools $^{8,9}$. Toncar ${ }^{10}$ reports on a study that uses the Service Learning Benefit Model to evaluate students' perception of service learning experiences using a multi-dimensional scheme. These studies focus on traditional SL.

The expectancy-value theory of motivation is predicated on the notion that "individuals choose behaviors based on the outcomes they expect and the values they ascribe to those expected outcomes." 11 This concept was pioneered by Atkinson ${ }^{12}$ and formulated into a mathematical model by Eccles et al. ${ }^{13}$. Wigfield et al. ${ }^{14}$ further developed the model concentrating on children and adolescents. Engineering education researchers have used it in a variety of studies, many within different contexts. Perhaps the most common use is in assessing student persistence and success in engineering ${ }^{15,16,17}$. Fowler and Meadows ${ }^{18}$ used it to evaluate the relationship between engineering design projects and gender. Panchal, et al. ${ }^{19}$ used the theory as a framework to develop a tool to design and assess an engineering design project in an upper division Systems Dynamics course. In their interpretation "the expectancy value theory posits that individual motivation for a task depends on perceptions about the odds of success on the task and the value of completing the task." They modeled the theory with the simple relation that motivation equals perceived probability of success in a task multiplied by the subjective task value.

In this study, expectancy-value theory is turned around. Instead of using it to predict or motivate a behavior, it is used to assess the perceived worth of an experience by assessing the value and expectation participants assign to an experience. The efficacy of the theory is dependent on isolating the factors most relevant to the specific situation. In the context of an ISL experience, participating students often enter with preconceived expectations and values that are strongly influenced by the non-student project leader. This is especially true when this role is held by a faculty member. Inherent trust in the professor as an authority figure is a strong force 
that is supported by the power dynamic between student and professor ${ }^{20}$. This dynamic can bias both what a student expects and values from an experience. Pancha ${ }^{19}$ identified four categories that characterize value (attainment, career, intrinsic and cost). This list has been expanded to reflect the items that are specific to ISL experiences with a humanitarian based mission. Eight key categories include:

- Intrinsic value, enjoyment experienced during and after the project

- Altruistic value, worth of the humanitarian mission

- Impact value, influence on a participants perspective on life

- Attainment value, personal importance of doing well

- Career value, benefit to career

- Cost value, aspects such as the commitment of time, money, physical and emotional effort

- Camaraderie value, quality of interactions with team members

- Community value, quality of interactions with community members

Expectations strongly influence an individual's motivation toward a behavior. Life is full of examples in which people "do things" (behavior) that exceed their supposed capabilities simply because of high expectations from authority figures: the Pygmalion effect. Rosenthal and Jacobsen $^{21,22}$ showed that high teacher expectation led to improved student performance in elementary school children and Bezuijen ${ }^{23}$ maintains that in the work place, manager expectations change employee behavior. If a manager (authority figure) treats an employee as a high producer then the employee becomes a high producer. Expectations can be both internal (self-imposed) and external (imposed by others) and both have the potential to be equally influential. In the context of this work, expectation is a modifier that accentuates a value. For example, if I place importance on altruistic value, and I have a high expectation that the experience has an important humanitarian mission, then this expectation strengthens the altruistic value of the experience. Naturally, anytime an expectation is met, the value of the experience increases. Conversely when expectations are not met or when they are low, the value is diminished.

Whether cognizant of it or not, every participant values different aspects of an experience differently and has expectations associated with each of these. Inevitably, attitudes held before the experience will likely change as the participant moves through the experience and ultimately they will continue to change after the experience, as reflection occurs over time. The relative importance of the value categories are subjective and will certainly vary from participant to participant. Indeed, it is the essence of perceived value that dictates that there is not a correct answer and that each participant's perceptions' defines their own ground truth. Any measure of perceived value must accommodate this principle.

\section{The Model}

The fundamental notion of the expectancy-value theory as applied in this work is based on identifying what a participant values about an experience and their expectations surrounding the outcome. Value is represented by both the importance and quality of the experience. To standardize the assessment the eight preset categories presented above are used. Participants rank the categories to capture individual preferences, Table I. Expectation and quality for each 
International Journal for Service Learning in Engineering, Humanitarian Engineering and Social Entrepreneurship Vol. 12, No. 1, pp. 1-12, Spring 2017

ISSN 1555-9033

category are set using 5 point Likert-type scales, Tables II and III respectively. Quality represents the level at which the expectation was met. For example, I might rank the altruistic value as third highest of the eight categories and rate quality of my experience, relative to this category, as much more gratifying than similar experiences I have had and lastly, I give it an expectation of highest. This process is repeated for each of the eight categories.

General demographic information is also collected on the student's class, when they participated, academic major, ethnicity and gender.

The assessment is implemented using a survey that comprises the three tables. Results are analyzed individually and in aggregate. The Likert scales are converted to the 1-5 numeric equivalent.

TABLE I

PARTICIPANTS RANK THE VALUE CATEGORIES BASED ON INDIVIDUAL IMPORTANCE

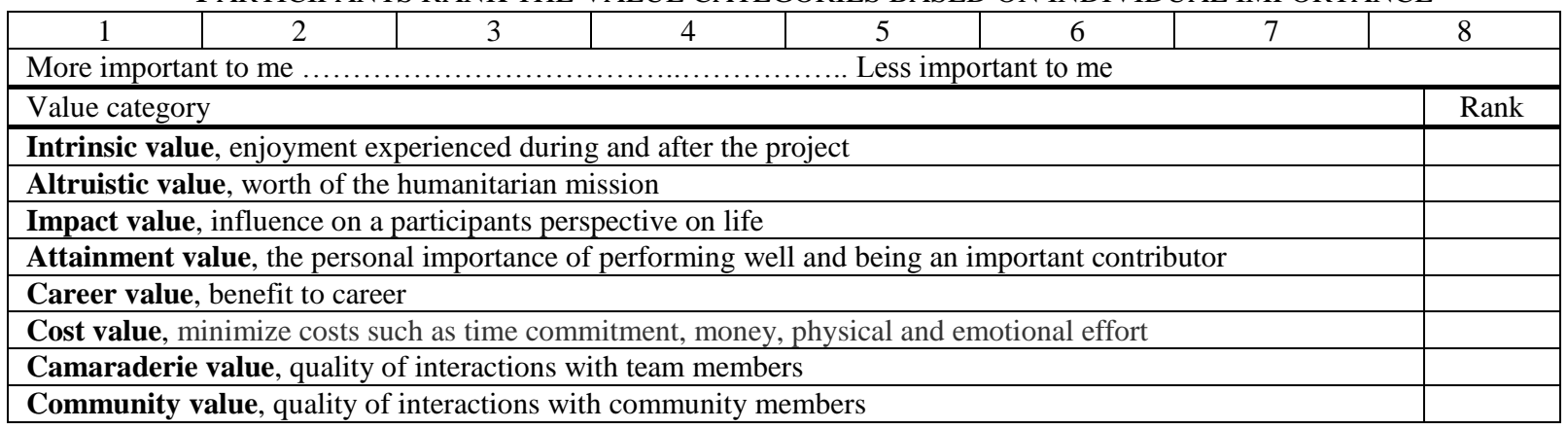

TABLE II

PARTICIPANTS RATE THEIR LEVEL OF EXPECTATION FOR EACH VALUE CATEGORY

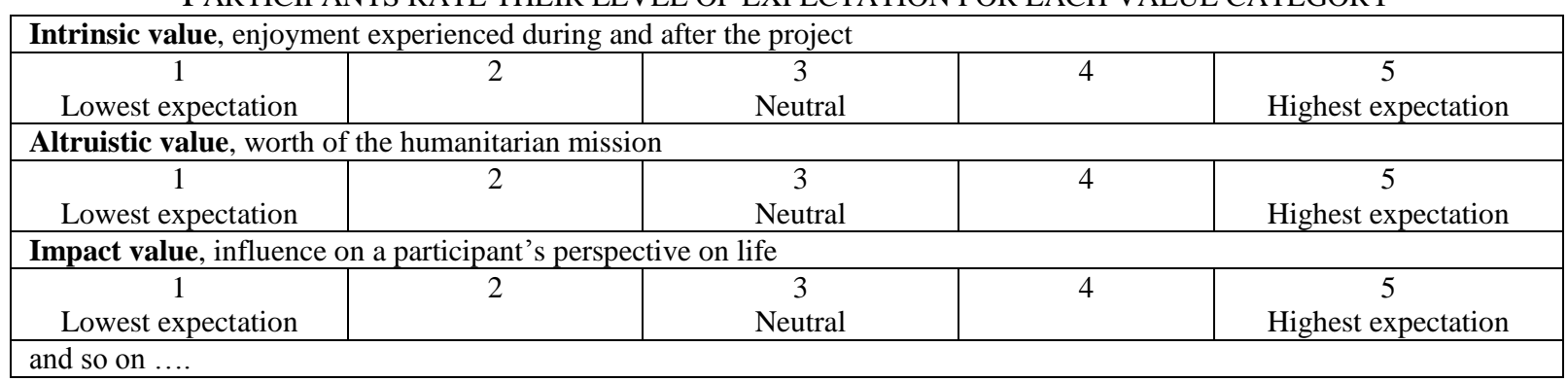

TABLE III

PARTICIPANTS RATE THE QUALITY OF THEIR EXPERIENCE FOR EACH VALUE CATEGORY Compared to other educational, volunteer or appropriately similar experiences that I have had; I rate this experience, Intrinsic value, enjoyment experienced during and after the project

\begin{tabular}{|c|c|c|c|c|}
\hline $\begin{array}{c}1 \\
\text { Much less gratifying }\end{array}$ & $\begin{array}{c}2 \\
\text { Less gratifying }\end{array}$ & $\begin{array}{c}3 \\
\text { About as same }\end{array}$ & $\begin{array}{c}4 \\
\text { More gratifying }\end{array}$ & $\begin{array}{c}5 \\
\text { Much more gratifying }\end{array}$ \\
\hline \multicolumn{5}{|c|}{ Altruistic value, worth of the humanitarian mission } \\
\hline $\begin{array}{c}1 \\
\text { Much less worthy }\end{array}$ & $\begin{array}{c}2 \\
\text { Less worthy }\end{array}$ & $\begin{array}{c}3 \\
\text { About as same }\end{array}$ & $\begin{array}{c}4 \\
\text { More worthy }\end{array}$ & $\begin{array}{c}5 \\
\text { Much more worthy }\end{array}$ \\
\hline \multicolumn{5}{|c|}{ Impact value, influence on a participants perspective on life } \\
\hline $\begin{array}{c}1 \\
\text { Much less impact }\end{array}$ & $\begin{array}{c}2 \\
\text { Less impact }\end{array}$ & $\begin{array}{c}3 \\
\text { About as same }\end{array}$ & $\begin{array}{c}4 \\
\text { More impact }\end{array}$ & $\begin{array}{c}5 \\
\text { Much more impact }\end{array}$ \\
\hline
\end{tabular}




\section{Case Study}

The Village Aid Project (VAP) at Fort Lewis College, Durango, CO has completed more than 25 humanitarian based projects in the developing world since 2005. Students work with faculty and community partners throughout the school year to complete the designs and prepare for the projects. Students then spend an intense two weeks implementing the project. During this period they live in the village and work closely with community members to construct the projects. Prior to traveling on a project, students are required to take a 1-credit course on sustainable technology and the developing world, but they do not receive academic credit for the preparatory work or the time spent, in-country, on implementation. While the program is centered in the engineering program, students from across campus participate. For example, students from 16 departments are represented in this study with $48 \%$ declaring themselves as engineers.

Data was collected using an online survey that was approved by the institutional review board. Since 2005, 286 student have participated in the program; contact information was available for 170 and $86(51 \%)$ responded to the survey. All surveys were administered after the ISL experience, some by more than 10 years.

\section{RESULTS}

Data on student perceived value can be used to assess a variety of factors including what is important to students, program strengths, weaknesses and overall efficacy.

What do students value most? There are several ways to assess student perceived value of their experience and the results are not necessary consistent. For example, student rankings of the eight value categories, shown in Table IV, places the importance of the humanitarian mission (altruistic) at the top, the (impact) of the experience on their life perspective as second and the enjoyment of the experience (intrinsic) as fifth. Seventy-six percent of the respondents indicated that they most highly valued either the altruistic or impact category and only 4.7 percent ranked the intrinsic category at the top. Figure 1 shows the fraction of students that ranked each category as either first or second in importance.

TABLE IV

OVERALL STUDENT RANKING OF THE VALUE CATEGORIES

\begin{tabular}{lrl} 
Category & Rank & $\begin{array}{c}\text { \% Who Chose } \\
\text { Rank }=1\end{array}$ \\
\hline Altruistic & 1 & $38.4 \%$ \\
Impact & 2 & $38.4 \%$ \\
Attainment & 3 & $4.7 \%$ \\
Community & 4 & $4.7 \%$ \\
Intrinsic & 5 & $4.7 \%$ \\
Camaraderie & 6 & $3.5 \%$ \\
Career & 7 & $3.5 \%$ \\
Cost & 8 & $2.3 \%$ \\
\hline
\end{tabular}



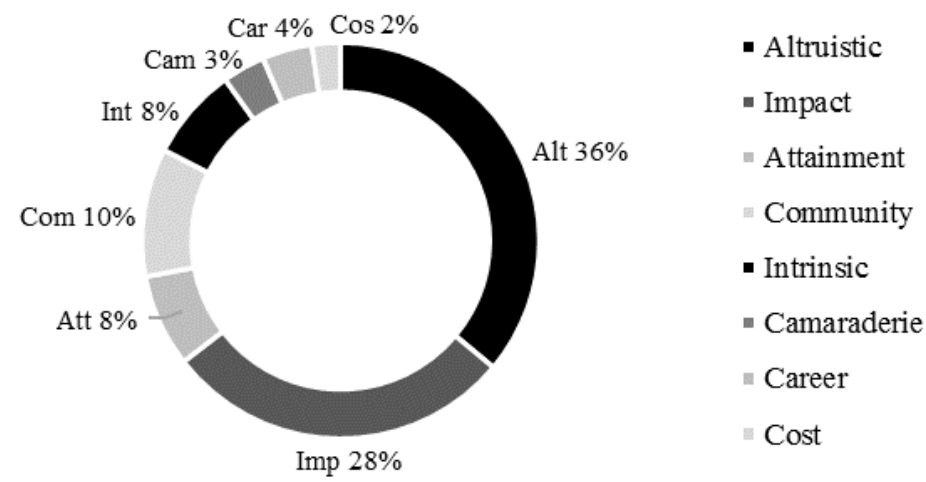

FIGURE 1

PERCENT OF PARTICIPANTS RANKING EACH VALUE CATEGORY AS EITHER $1^{\text {ST }}$ OR $2^{\text {ND }}$ HIGHEST IN IMPORTANCE

Using a composite score, defined as the expectation rating multiplied by the quality (value) rating, altruistic was the highest (18.6), intrinsic was second (17.6) and impact third (17.2) (Figure 2). In contrast, a third measure is the fraction of students who gave the highest quality rating (5) to a category. In this case the order is intrinsic (77\%), impact (74\%) and altruistic (57\%). These different measures of importance are summarized in Table V. The remainder of the value categories garnered little support with the cost to the student (financial, time, effort) ranking the lowest.

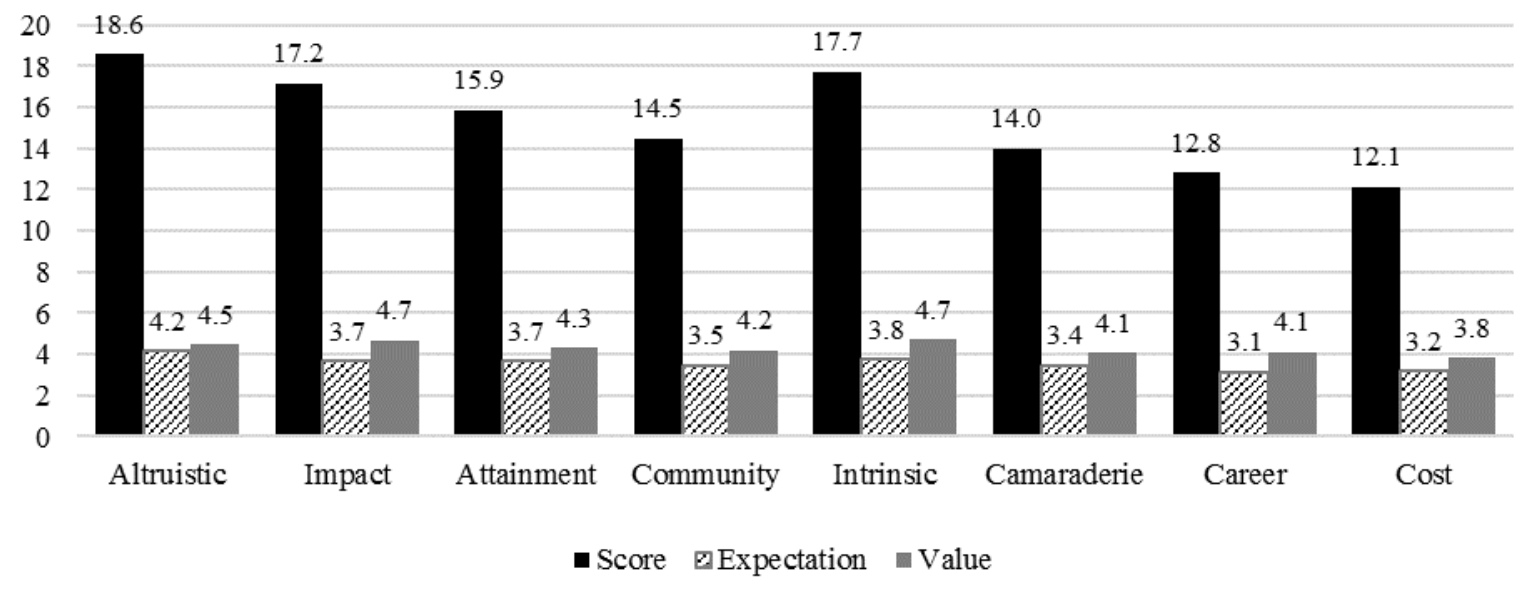

FIGURE 2

AVERAGE RATING OF EXPECTATIONS AND QUALITY (VALUE) FOR EACH CATEGORY BASED ON DATA FROM ALL PARTICIPANTS 
TABLE V

COMPARISON OF IMPORTANCE RATINGS STUDENTS GIVE TO VALUE CATEGORIES

\begin{tabular}{lccc} 
Category & Rank & $\begin{array}{l}\text { Composite } \\
\text { Score }\end{array}$ & $\begin{array}{l}\text { Percent Giving } \\
\text { Highest Quality } \\
\text { Rating (5) }\end{array}$ \\
\hline Altruistic & 1 & 1 & 3 \\
Impact & 2 & 3 & 2 \\
Intrinsic & 5 & 2 & 1 \\
\hline
\end{tabular}

\section{Program Strengths, Weaknesses and Efficacy}

Program effectiveness is evaluated by comparing the expectation and quality (value) ratings. In all cases, students rated the quality of their experience as greater than the median Likert scale value of 3 and in most cases the rating was above 4. As seen in Figure 2, for all eight categories,

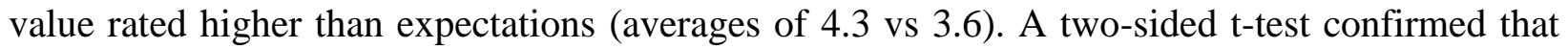
the difference between the expectation and value averages are statistically significant with a pvalue of less than 0.0005 , or a probability of $99.95 \%$.

One interpretation would be that students simply had low expectations and this comparison says nothing about the value of the experiences. However, since the average expectation rating (3.6) is well above the median Likert value of (3), it is reasonable to conclude that, in the eyes of participants, expectations were not low but relatively high and that value of the experience exceeded expectations. In addition, students confidently rated the value of their experience (4.3) as significantly better than other similar experiences they have had.

The composite scores shown in Figure 2 for the four top rated categories are statistically different than the bottom four ( $\mathrm{p}=0.005$ ) with group averages of 17.4 vs 13.4 respectively. This suggests that the program could be improved by working to enhance the four lower rated categories (community, camaraderie, career and cost). When the three program directors (faculty) were asked to rank the eight value categories, the order was the same as the average ranking given by students (Table IV).

A summary of these statistical tests are given in Table VI.

TABLE VI

SUMMARY OF STATISTICAL TESTS

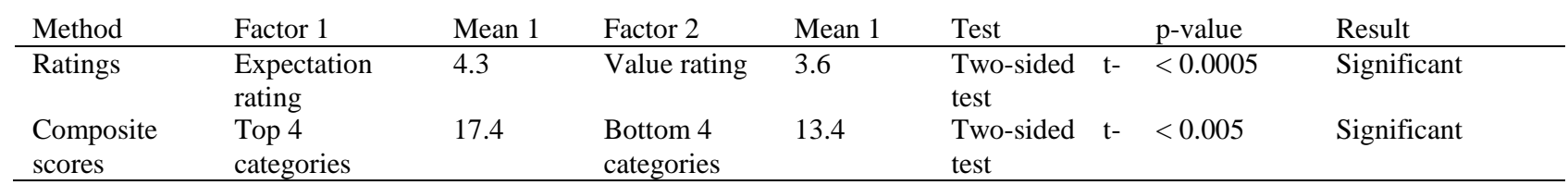

\section{Engineers}

Engineering students represent about half (48\%) of the study participants. The data was sorted on student major and the analyses were repeated. Figure 3 shows the distribution of score, 
expectation and value. As in Figure 2, the order of the categories correspond to their rank (left=1, right=8). Engineering students gave the same ranking order as the total population except for the intrinsic and community categories which changed places. Overall, the composite scores are slightly different than for the total group but the difference is not statistically significant $(\mathrm{p}=0.1$ to 0.25$)$. Therefore no conclusions can be made.

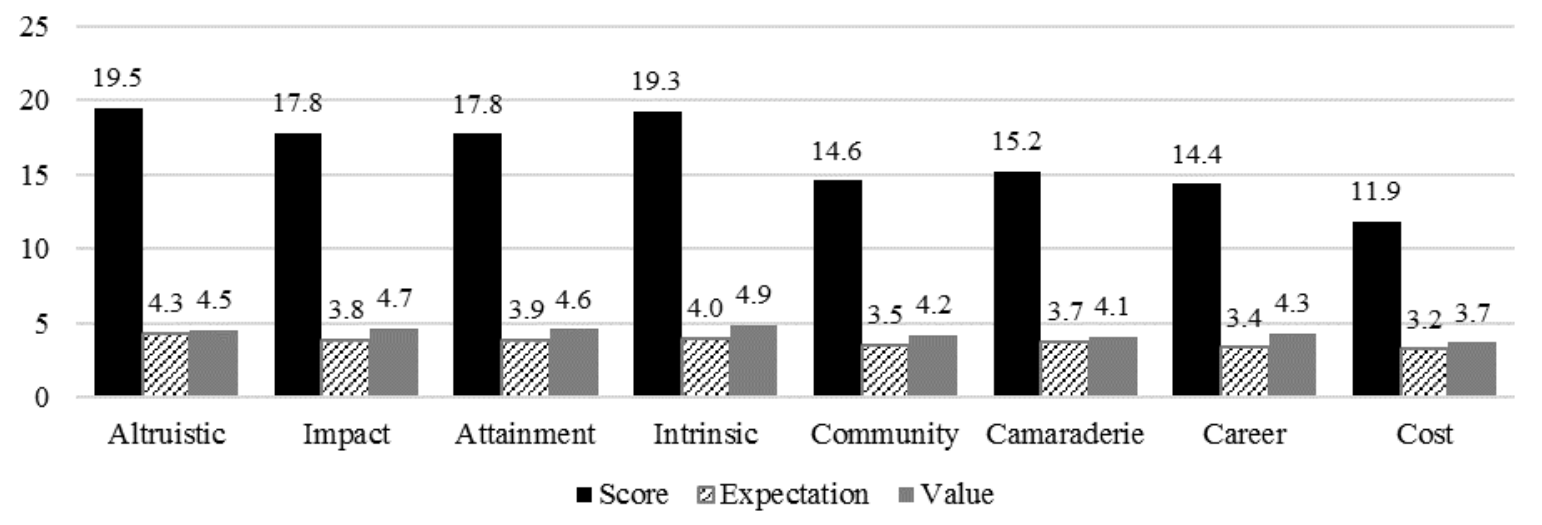

FIGURE 3

AVERAGE RATING OF EXPECTATION AND VALUE (QUALITY) FOR EACH CATEGORY BASED ON DATA FROM ENGINEERING STUDENTS

Altruism and the impact on life perspective proved to be important factors for nearly all students. Another critical category, attainment, is defined as the personal importance of performing well and being an important contributor. On all VAP projects, students are responsible for the success of key components. This is especially critical for engineering students who take leadership roles in the design and construction of the technical components that ultimately control whether a project succeeds or fails. The average attainment score for engineers is 18.5 compared to 16.5 for non-engineers. The difference between these is not statistically significant. However the relatively high score for attainment indicates that engineering students place a higher value on personal performance than most other categories.

\section{Gender}

Fifty-three percent of study participants were female and of those $19 \%$ were engineering students. Of the $47 \%$ of male students, $55 \%$ declared their major as engineering. Out of the eight value categories, only "attainment" resulted in a difference between the female and male expectancy-value score that was statistically different, 15.2 and 16.9 respectively. Female students reported both lower expectations and perceived quality (value) for this category. As discussed previously, engineers value "attainment" and hence a portion of this gender based discrepancy could be explained by the fact that the male population contains more engineers than the female. Another interpretation is that female students do not feel as confident in their ability to perform well and therefore do not value this category as much as males. This notion is supported by $\mathrm{Cech}^{24}$, Chachra ${ }^{25}$ and others who have studied gender persistence in male dominated engineering and other STEM disciplines. Building professional role confidence in the 
early stages of a career is critical to long term professional confidence for women in engineering ${ }^{24}$.

\section{DISCUSSION}

\section{Student Perceived Value}

The apparent contradiction between the different measures (category ranking, composite score and quality rating) of what students value most is, at least partially, embedded in the context and the way the question is asked. In the first case (ranking), students are asked to simply rank the eight value categories against each other. This was the first thing respondents did when completing the survey and hence they had not yet considered their expectations or their assessment of quality. The composite score explicitly takes account of both expectations and quality of the experience and thus may be the most descriptive. The third measure, while not inclusive, is important to consider especially since, in general, people are much less likely to choose the extremes of a Likert type scale ( 1 or 5 ). While there is no definitive method for establishing the order of these categories, it is quite clear that students highly value the humanitarian nature of the projects and that these types of projects have life changing impacts. Given this conclusion, it is also important that the experience be enjoyable.

\section{Pygmalion Effect}

The student ranking of the 8 value categories mirrored the faculty director's rankings. While not conclusive, this fact does support the notion of the Pygmalion effect, that when an authority figure has high expectations for a specific action the student will adopt the same mentality. It lends support to employing this tactic by simply having the program directors place more importance on the lower rated categories with the anticipated outcome that student expectations will also increase. Of course, the other half of this effort should be to find ways to increase the quality of the experiences associated with these categories.

\section{Millennials}

The millennial generation (ages 18-34 in 2015) is the largest generational demographic in the United States ${ }^{26}$ and represents the vast majority of current college age students. An article in Time magazine entitled Millennials: The Me Me Me Generation ${ }^{27}$ characterized this group as lazy, entitled, and narcissistic. The data collected in this study paints a different picture, at least for the self-selected subset of millennials that participate in this type of ISL experiences. According to the ranking data they most value helping improve the quality of life for the poor and the fact that this experience changed their perspective on life. These types of experiences seem to promote a less self-focused perspective in student. It must also be conceded that millennials want to have fun (intrinsic category). Don't we all?

Results from this study can be actively used to improve the student experience. For example, Panchal, et al. ${ }^{19}$ concluded that, "at a fundamental level, faculty can (1) increase student beliefs about their odds of success through the proper structuring of a project and mentoring as the project is ongoing, and (2) increase student perceptions of project value ..."

The following conclusions and recommendation are drawn from this study: 
International Journal for Service Learning in Engineering, Humanitarian Engineering and Social Entrepreneurship Vol. 12, No. 1, pp. 1-12, Spring 2017

ISSN 1555-9033

1. Students rated both expectations and the value (quality) of the ISL experience well above the median Likert scale value indicating that they highly value their experience and validating the effectiveness of the program.

2. Students select altruism, impact, intrinsic and attainment as the four highest rated/ranked value categories. These categories are rated significantly higher than the remaining four and represent strengths of the program.

3. Overall project effectiveness can be improved by increasing student expectations. Having the faculty directors place more importance on the lower rated categories would be an easy way to start this process.

4. Students give a low rank/rating (seven out eight) to the benefit of the ISL experience to their career. For engineering students, in addition to the technical and project management skills acquired, anecdotal evidence from employers indicates that this type of experience often plays an important role in the hiring process. The benefit to career goal should be developed.

5. Many students only moderately expect that they have a high probability of success (expectation) but they highly value the experience. This suggests that more should be done, in advance of the project, to develop competence and bolster confidence in their ability to succeed.

6. The value categories most important to the faculty directors are also the highest rated by the students indicating goals and outcomes that are aligned.

7. Professional role confidence in female students is a possible explanation for their lower "attainment" scores (compared to males). This could be addressed by developing an organizational culture in which women are not only encouraged but expected to take leadership roles on engineering tasks and then given the support needed to succeed.

\section{REFERENCES}

1. J. Dewey, "Experience and Education", Macmillan, (1938).

2. Robert L. Sigmon, "Service-learning: Three Principles. Synergist. National Center for Service-Learning", ACTION, 8(1):9-1 1 (Spring 1979).

3. G.D. Kuh, "High-Impact Educational Practices - What they are, who has access to them, and why they matter", Association of American Colleges and Universities, (2008).

4. National Study of Student Engagement, "Experiences That Matter: Enhancing Student Learning and Success", Indiana University Center for Postsecondary Research, Bloomington, IN, (2007).

5. J.W. Roberts, "Experiential Education in the College Context: What is it, how it works, and why it matters", Routledge - Taylor \& Francis publ, (2016).

6. R.D. Shumer, P. Duttweiler, A. Furco, M.S. Hengel, and G. Willems, "Shumer's Self-Assessment for Service Learning", Service Learning, (2000). Retrieved from: http://digitalcommons.unomaha.edu/slceslgen/145

7. S.J. Steimel, "Community Partners' Assessment of Service Learning in an Interpersonal and Small Group Communication Course", Communication Teacher, (2013) 1-15.

8. R.G. Bringle, M.A. Phillips and M. Hudson, "The Measure of Service Learning - Research Scales to Assess Student Experiences", American Psychological Association (2004).

9. Purdue Libraries, "Service Learning: Service Learning Assessment Tools, A research guide for service learning and civic engagement", Retrieved from: http://guides.lib.purdue.edu /c.php?g=352961\&p=2378210.

10. M. Toncar, J. Reid, D. Burns, C. Anderson, and H. Nguyen, "Uniform Assessment of the Benefits of Service Learning: The Development, Evaluation, and Implementation of the Seleb Scale". Journal of Marketing Theory and Practice, 14(3), (2006) 223-238. Retrieved from http://www.jstor.org/stable/40470267

11. A. Borders, M. Earleywine, and S. Huey, "Predicting Problem Behaviors with Multiple Expectancies: Expanding Expectancy Value Theory", Adolescence, 39(155), (2004), 539-551. 
International Journal for Service Learning in Engineering, Humanitarian Engineering and Social Entrepreneurship Vol. 12, No. 1, pp. 1-12, Spring 2017

ISSN 1555-9033

12. J.W. Atkinson, "Motivational determinants of risk taking behavior," Psychological Review, 64, (1957), 359372.

13. J.S. Eccles, T.F. Adler, R. Futterman, S.B. Goff, C.M. Kaczala, J.L. Meece and C. Midgley, "Expectancies, values, and academic behaviors", Achievement and achievement motives: Psychological and sociological approaches, edited by J.T. Spence, W.H. Freeman and Company, San Francisco CA, (1983) 75-146.

14. Wigfield, and J Eccles, "Expectancy-Value Theory of Achievement Motivation", Contemporary Educational Psychology, 25(1), (2000), 68-81.

15. H. Matusovich, R. Streveler, H. Loshbaugh, R. Miller and B. Olds, "Will I Succeed in Engineering? Using Expectancy-Value Theory in a Longitudinal Investigation of Students' Beliefs", Research Brief - Center for the Advancement of Engineering Education, Univ of Washington, Proceedings of American Society for Engineering Education Conference, (2008).

16. B.D. Jones, M.C. Paretti, S.F. Hein and T.W. Knott, "An Analysis of Motivation Constructs with First-Year Engineering Students: Relationships Among Expectancies, Values, Achievements, and Career Paths”, Journal of Engineering Education, (Oct 2010), 319-336.

17. C.A. McGrath, K. Gipson, O. Pierrakos and M. Peterson, "An evaluation of freshman engineering persistence using Expectancy-Value Theory", Proceedings - Frontiers in Education Conference, (Sept 2013).

18. R. Fowler, and L.A. Meadows, "Assessing Gender Differences in First-Year Student Motivation", $120^{\text {th }}$ ASEE Annual Conference and Exposition, American Society for Engineering Education, (2013).

19. J. H. Panchal, O. Adesope, and R. Malak, "Designing Undergraduate Experiences - A Framework based on the Expectancy-value Theory", International Journal of Engineering Education, vol 28, No. 4, (2012), 871-879.

20. P. Schrodt, P.L. Witt and P.D. Turman, "Reconsidering the Measurement of Teacher Power Use in the College Classroom", Communication Education, v56 n3 p308-332 (Jul 2007).

21. R. Rosenthal and L. Jacobson, "Pygmalion in the classroom". New York: Holt, Rinehart \& Winston, (1968).

22. R. Rosenthal and L. Jacobson, "Pygmalion in the classroom" (Expanded ed.). New York: Holt, Rinehart \& Winston, (1992).

23. X. Bezuijen, P. van den Berg, K. van Dam, and H. Thierry, "Pygmalion and employee learning: The role of leader behaviors", Journal of Management, 35(5), (2009) 1248-1267.

24. E. Cech, B. Rubineau, S. Silbey, and C. Seron, "Professional Role Confidence and Gendered Persistence in Engineering", American Sociological Review, Am. Soc. Assoc. (Sept. 28, 2011).

25. D. Chachra, and D. Kilgore, "Exploring gender and self-confidence in engineering students: A multi-method approach", Research Brief, Center for the Advancement of Engineering Education, Proceedings American Society for Engineering Education Conference, (2009).

26. R. Fry, "Millennials overtake Baby Boomers as America's largest generation”, Pew Research Center, (April 25, 2016). Retrieved from http://www.pewresearch.org/fact-tank/2016/04/25/millennials-overtake-baby-boomers/

27. J. Stein, “The Me Me Me Generation”, Time, (May 2013). 